\title{
Clostridium difficile-associated diarrhea (CDAD) and proton pump inhibitor therapy: CAG Position Statement
}

\author{
Canadian Association of Gastroenterology, Clinical Affairs
}

\begin{abstract}
In light of the recent data and an advisory from Health Canada (http://www.phac-aspc.gc.ca/c-difficile/index.html), the Canadian Association of Gastroenterology (CAG) has prepared the following position statement on the role of proton pump inhibitors (PPIs) in Clostridium difficile-associated diarrhea (CDAD) which we hope will be of use to members, other health care professionals and patients across the country.
\end{abstract}

PPIs are safe and effective medications

PPIs are among the most widely prescribed medications worldwide (1) and have been used for over 15 years with an excellent safety profile (2-7). They comprise the drug class of choice for managing patients with complicated gastroesophageal reflux disease (GERD) (8) as well as uncomplicated GERD (9) and many other chronic acid-related conditions. In these conditions, PPI use is associated with improvements in endoscopic outcome, symptoms and quality of life (for indications that include initial therapy, maintenance treatment and prophylactic use) (2-6,8-16). Furthermore, they have been found to improve patient outcomes in acute upper gastrointestinal hemorrhage (17), and more specifically, in those patients with bleeding peptic ulcers (18).

Only evidence-based and appropriate utilization of PPIs should be encouraged, and this will lead to their cost-effective use

Recent data suggest that overutilization of PPIs is common, especially in their intravenous form in the hospital setting (1922). Although this class of medications appears to be both cheaper and more effective than alternatives in the management of high-risk patients with bleeding ulcers (23-29), such cost-effective utilization is only realised if PPIs are used for appropriate indications.

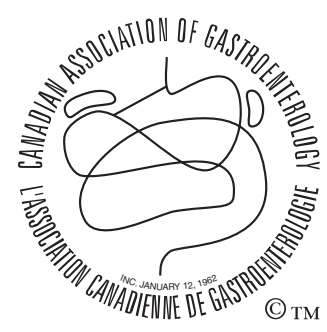

En français voir page 377
Recent exploratory data suggest a possible association between the use of PPIs and CDAD in a selected subgroup of hospitalized patients

The widely accepted risk factors for the development of CDAD include exposure to antibiotics (the most common), especially those with a broad-spectrum activity (30); increasing age or illness severity (31-33); hospitalization (34) or residence in a long-term care facility (35); increasing duration of hospital stay (36); and exposure to chemotherapeutic or immunosuppressive agents (37). Additional possible risk factors have included gastrointestinal surgery and the use of nasogastric tubes, stool softeners, gastrointestinal stimulants, antiperistaltic drugs, antacids and enemas (31-33). A recent publication has reviewed this topic (38).

Although limited data to date have shown that decreased gastric acidity leads to prolonged $\mathrm{C}$ difficile organism or toxin survival (39) or to other infectious diarrheal illnesses (40), a very recent report (41) suggests that PPI utilization is associated with community-acquired pneumonia. CDAD has also been linked to $\mathrm{H}_{2}$-receptor antagonist use in an American period prevalence survey (35), and to PPI use in an American casecontrol study (42).

A recent $C$ difficile outbreak in Quebec (43) has facilitated additional research on the topic. A report that included both a cohort study and a case-control study (44) has suggested that a strong association may exist between the use of PPIs and the occurrence of CDAD (OR approximately 2.5). Unfortunately, these studies have been retrospective, and based on limited data that did not take into consideration a number of important variables relating to hygiene practices. Also, the analyses may not have adequately accounted for other known confounding variables. Nonetheless, these results point to a possible causal association between PPI use and the development of

The CAG is proud to acknowledge its Benefactor Corporate Sponsors:
Abbott Laboratories Ltd
AstraZeneca Canada Inc
Axcan Pharma Inc
Janssen-Ortho Inc
Pfizer Canada Inc
Schering Canada Inc 
CDAD, at least in a specific patient population, and warrant further research. It is important to note that the population found to be at risk in the most recent studies was comprised of older (mean age 73 to 76 years), particularly sick in-patients (14\% renal failure, $22 \%$ diabetes and $25 \%$ cancer), who were also prescribed antibiotics. In fact, in only one of 94 cases did the patient develop CDAD on a PPI while off antibiotics. Currently, there exist no published data establishing an association between PPI use and CDAD in an out-patient setting.

The generalizability of the situation currently experienced in Quebec remains in question not only vis-à-vis the type of patients affected, but also with regard to the actual bacterial strain involved. Indeed, in the Quebec outbreak, as for those noted in five American states, it would appear that a special "binary toxin positive" strain (in addition to the production of toxins $\mathrm{A}$ and $\mathrm{B}$ ) has been implicated as the dominant clone (Louie $\mathrm{T}$, personal communication). But only approximately $5 \%$ of all C difficile strains produce such a binary toxin, which may be responsible for increased pathogenicity. The situation in Quebec, and results generated from the outbreak, may thus also be region-specific. Quinolone resistance has been raised as a possible additional issue.

\section{The risks and benefits of administering or discontinuing a PPI for a given patient needs to be carefully assessed on a case-by-case basis}

Because of the proven benefits of PPI administration in patients with appropriate indications, a decision not to initiate PPI treatment needs to be taken after carefully weighing the risks and benefits for that particular patient. The highly selected nature of the patient population that appears to be at added risk for CDAD disease with PPI usage, again needs to be emphasized. The CAG wishes to remind health professionals of the importance of appropriate antibiotic prescribing and sound hygiene practices as recognized components to controlling C difficile-related illness (38,45,46).

\section{The CAG encourages its members, and indeed all health professionals, to keep abreast of any additional publications of relevant data}

It is very likely that clinically relevant animal and human data will soon emerge to further characterize a possible association between the use of PPIs and C difficile in various clinical settings. Health professionals are strongly advised to keep abreast of this evolving area of research, and the CAG will endeavor to disseminate up-to-date information and provide guidance in the form of position statements such as this one, or in the form of more extensively developed consensus guidelines, if and when appropriate.

\section{REFERENCES}

1. Gregor JC. Acid suppression and pneumonia: A clinical indication for rational prescribing. JAMA 2004;292:2012-3.

2. Dent J, Talley NJ. Overview: Initial and long-term management of gastro-oesophageal reflux disease. Aliment Pharmacol Ther 2003;17(Suppl 1):53-7.

3. Freston JW. Long-term acid control and proton pump inhibitors: Interactions and safety issues in perspective. Am J Gastroenterol 1997;92:51S-5; discussion 55S-7S.

4. Klinkenberg-Knol EC, Festen HP, Meuwissen SG. Pharmacological management of gastro-oesophageal reflux disease. Drugs 1995;49:695-710.
5. Lamberts R, Brunner G, Solcia E. Effects of very long (up to 10 years) proton pump blockade on human gastric mucosa. Digestion 2001;64:205-13.

6. Tutuian R, Castell DO. Management of gastroesophageal reflux disease. Am J Med Sci 2003;326:309-18.

7. Reilly JP. Safety profile of the proton-pump inhibitors. Am J Health Syst Pharm 1999;56:S11-7.

8. Jankowski J, Sharma P. Review article: Approaches to Barrett's oesophagus treatment-the role of proton pump inhibitors and other interventions. Aliment Pharmacol Ther 2004;19(Suppl 1):54-9.

9. Armstrong D, Marshall J, Chiba N, et al. Canadian Consensus Conference on the Management of Gastroesophageal Reflux Disease in adults - Update 2004. Can J Gastroenterol. 2005;19:15-35.

10. Chan FK, Graham DY. Review article: Prevention of non-steroidal anti-inflammatory drug gastrointestinal complications-review and recommendations based on risk assessment. Aliment Pharmacol Ther 2004;19:1051-61.

11. Mikek M, Vidmar G, Tonin M, Pavlovcic V. Fracture-related and implant-specific factors influencing treatment results of comminuted diaphyseal forearm fractures without bone grafting. Arch Orthop Trauma Surg 2004;124:393-400.

12. Welage LS. Pharmacologic features of proton pump inhibitors and their potential relevance to clinical practice. Gastroenterol Clin North Am 2003;32:S25-35.

13. Welage LS. Pharmacologic properties of proton pump inhibitors. Pharmacotherapy 2003;23:74S-80S.

14. Katz PO, Frissora C. The pharmacology and clinical relevance of proton pump inhibitors. Curr Gastroenterol Rep 2002;4:459-62.

15. Veldhuyzen van Zanten SJ, Flook N, Chiba N, et al. Update from the Canadian Dyspepsia Working Group. CMAJ 2000;163:696.

16. Veldhuyzen van Zanten SJ, Flook N, Chiba N, et al. An evidencebased approach to the management of uninvestigated dyspepsia in the era of Helicobacter pylori. Canadian Dyspepsia Working Group. CMAJ 2000;162:S3-23.

17. Barkun A, Sabbah S, Enns R, et al. The Canadian Registry on Nonvariceal Upper Gastrointestinal Bleeding and Endoscopy (RUGBE): Endoscopic hemostasis and proton pump inhibition are associated with improved outcomes in a real-life setting. Am J Gastroenterol 2004;99:1238-46.

18. Barkun A, Bardou M, Marshall JK. Consensus recommendations for managing patients with nonvariceal upper gastrointestinal bleeding. Ann Intern Med 2003;139:843-57.

19. Arasaradnam RP, Woodward T, Parrack L, Bartlett J, Bolton RP. Audit of proton pump inhibitor (PPI) prescribing: Are NICE guidelines being followed? Clin Med 2003;3:387-8.

20. Enns R, Andrews CN, Fishman M, et al. Description of prescribing practices in patients with upper gastrointestinal bleeding receiving intravenous proton pump inhibitors: A multicentre evaluation. Can J Gastroenterol 2004;18:567-71.

21. Guda NM, Noonan M, Kreiner MJ, Partington S, Vakil N. Use of intravenous proton pump inhibitors in community practice: An explanation for the shortage? Am J Gastroenterol 2004;99:1233-7.

22. Sturkenboom MC, Burke TA, Tangelder MJ, Dieleman JP, Walton $\mathrm{S}$, Goldstein JL. Adherence to proton pump inhibitors or $\mathrm{H}_{2}$ receptor antagonists during the use of non-steroidal antiinflammatory drugs. Aliment Pharmacol Ther 2003;18:1137-47.

23. Erstad BL. Cost-effectiveness of proton pump inhibitor therapy for acute peptic ulcer-related bleeding. Crit Care Med 2004:32:1277-83.

24. Barkun AN, Herba K, Adam V, Kennedy W, Fallone CA, Bardou $\mathrm{M}$. The cost-effectiveness of high-dose oral proton pump inhibition after endoscopy in the acute treatment of peptic ulcer bleeding. Aliment Pharmacol Ther 2004;20:195-202.

25. Barkun AN, Herba K, Adam V, Kennedy W, Fallone CA, Bardou $\mathrm{M}$. High-dose intravenous proton pump inhibition following endoscopic therapy in the acute management of patients with bleeding peptic ulcers in the USA and Canada: A costeffectiveness analysis. Aliment Pharmacol Ther 2004;19:591-600.

26. Enns RA, Gagnon YM, Rioux KP, Levy AR. Cost-effectiveness in Canada of intravenous proton pump inhibitors for all patients presenting with acute upper gastrointestinal bleeding. Aliment Pharmacol Ther 2003;17:225-33.

27. Gagnon YM, Levy AR, Eloubeidi MA, Arguedas MR, Rioux KP, Enns RA. Cost implications of administering intravenous proton pump inhibitors to all patients presenting to the emergency department with peptic ulcer bleeding. Value Health 2003;6:457-65. 
28. Lee KK, You JH, Wong IC, et al. Cost-effectiveness analysis of highdose omeprazole infusion as adjuvant therapy to endoscopic treatment of bleeding peptic ulcer. Gastrointest Endosc 2003;57:160-4.

29. Spiegel BM, Ofman JJ, Woods K, Vakil NB. Minimizing recurrent peptic ulcer hemorrhage after endoscopic hemostasis: The costeffectiveness of competing strategies. Am J Gastroenterol 2003;98:86-97.

30. Bignardi GE. Risk factors for Clostridium difficile infection. J Hosp Infect 1998;40:1-15.

31. Barbut F, Petit JC. Epidemiology of Clostridium difficile-associated infections. Clin Microbiol Infect 2001;7:405-10.

32. Simor AE, Yake SL, Tsimidis K. Infection due to Clostridium difficile among elderly residents of a long-term-care facility. Clin Infect Dis 1993;17:672-8.

33. McFarland LV, Surawicz CM, Stamm WE. Risk factors for Clostridium difficile carriage and C. difficile-associated diarrhea in a cohort of hospitalized patients. J Infect Dis 1990;162:678-84.

34. Levy DG, Stergachis A, McFarland LV, et al. Antibiotics and Clostridium difficile diarrhea in the ambulatory care setting. Clin Ther 2000;22:91-102.

35. Walker KJ, Gilliland SS, Vance-Bryan K, et al. Clostridium difficile colonization in residents of long-term care facilities: Prevalence and risk factors. J Am Geriatr Soc 1993;41:940-6.

36. Johnson S, Clabots CR, Linn FV, Olson MM, Peterson LR, Gerding DN. Nosocomial Clostridium difficile colonisation and disease. Lancet 1990;336:97-100.

37. Blot E, Escande MC, Besson D, et al. Outbreak of Clostridium difficile-related diarrhoea in an adult oncology unit: Risk factors and microbiological characteristics. J Hosp Infect 2003;53:187-92.

38. Poutanen SM, Simor AE. Clostridium difficile-associated diarrhea in adults. CMAJ 2004;171:51-8.

39. Gurian L, Ward TT, Katon RM. Possible foodborne transmission in a case of pseudomembranous colitis due to Clostridium difficile: Influence of gastrointestinal secretions on Clostridium difficile infection. Gastroenterology 1982;83:465-9.

40. Williams C. Occurrence and significance of gastric colonization during acid-inhibitory therapy. Best Pract Res Clin Gastroenterol 2001; 15:511-21

41. Laheij R, Sturkenboom M, Hassing R, Dieleman J, Stricker B, Jansen J. Risk of community-acquired pneumonia and use of gastric acid-suppressive drugs. JAMA 2004;292:1955-60.

42. Cunningham R, Dale B, Undy B, Gaunt N. Proton pump inhibitors as a risk factor for Clostridium difficile diarrhoea. J Hosp Infect 2003;54:243-5.

43. Pepin J, Valiquette L, Alary ME, et al. Clostridium difficile-associated diarrhea in a region of Quebec from 1991 to 2003: A changing pattern of disease severity. CMAJ 2004;171:466-72.

44. Dial S, Alrasadi K, Manoukian C, Huang A, Menzies D. Risk of Clostridium difficile diarrhea among hospital inpatients prescribed proton pump inhibitors: Cohort and case-control studies. CMAJ 2004;171:33-8

45. Loo VG, Libman MD, Miller MA, et al. Clostridium difficile: A formidable foe. CMAJ 2004;171:47-8.

46. Louie TJ, Meddings J. Clostridium difficile infection in hospitals: Risk factors and responses. CMAJ 2004;171:45-6. 


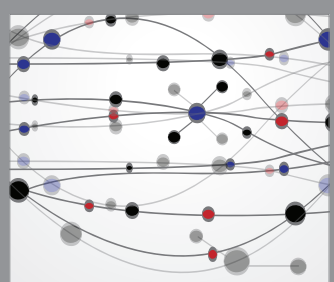

The Scientific World Journal
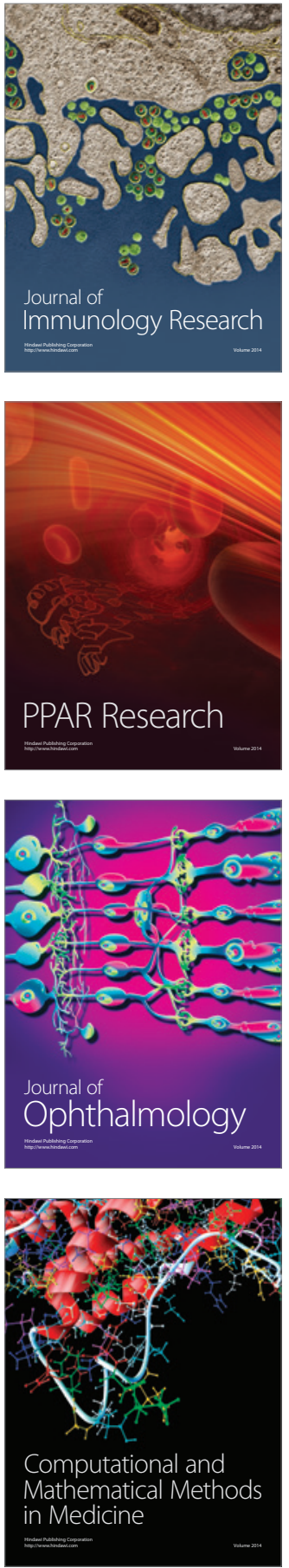

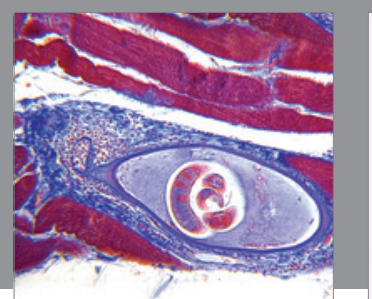

Gastroenterology Research and Practice

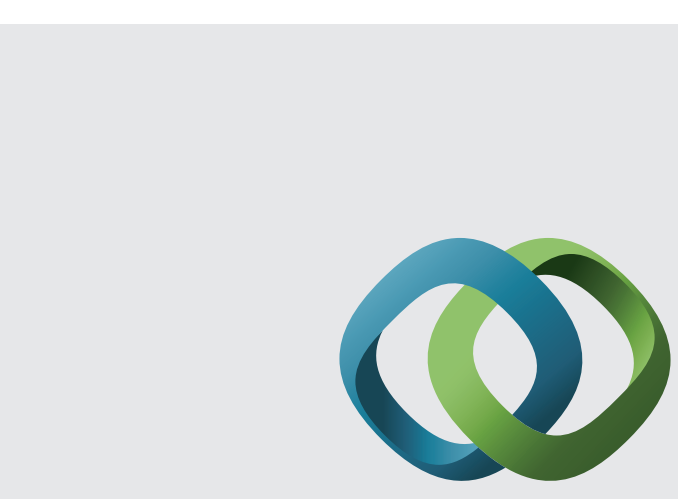

\section{Hindawi}

Submit your manuscripts at

http://www.hindawi.com
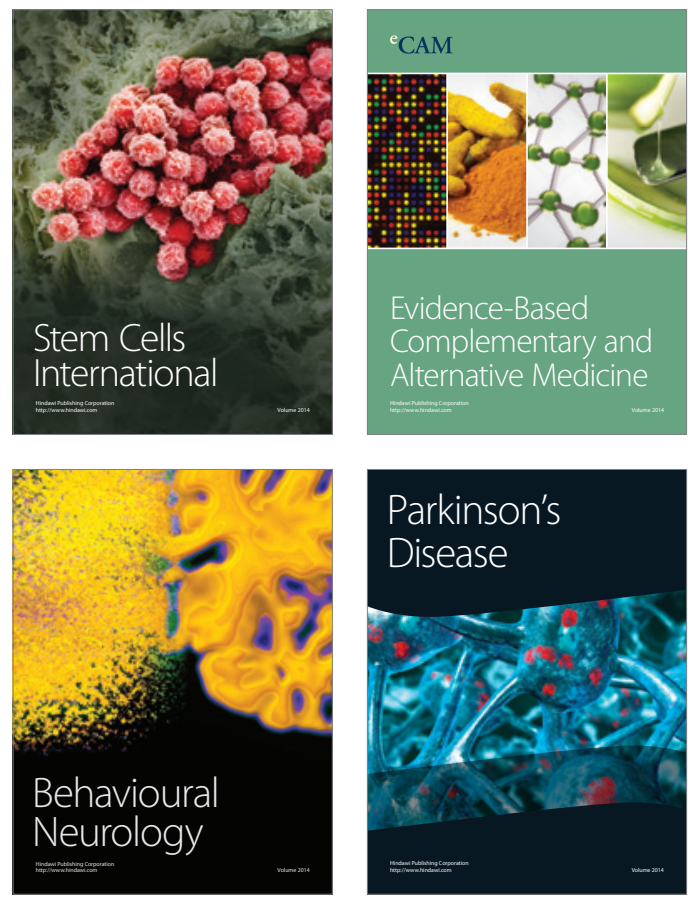
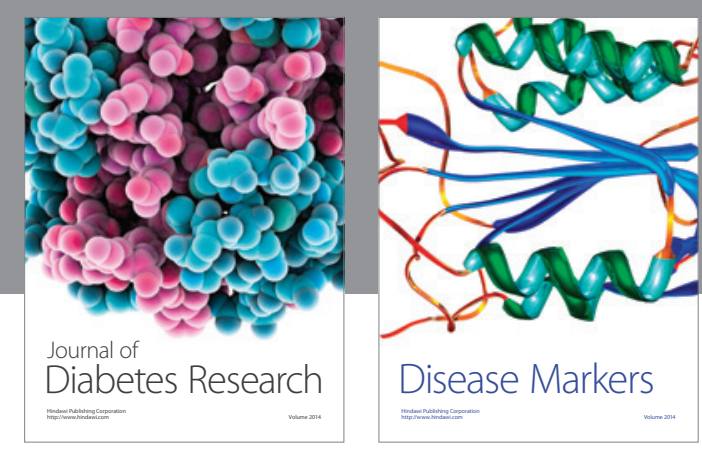

Disease Markers
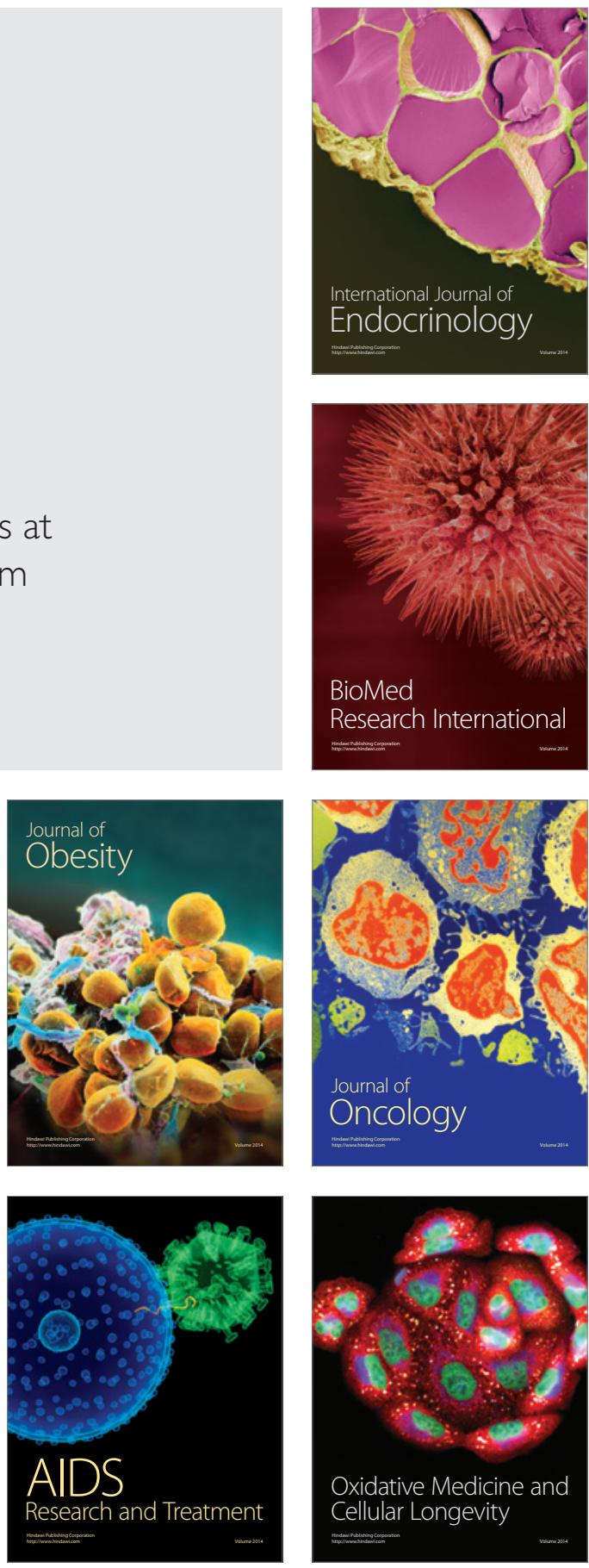